\title{
Penentuan Struktur Bawah Permukaan Daerah Geothermal Menggunakan Metode Geolistrik di Desa Penen Kecamatan Biru Biru Kabupaten Deli Serdang
}

\author{
Muhammad Kadri ${ }^{1,2}$ Teguh Febri Sudarma' \\ 'Fakultas Matematika dan Ilmu Pengetahuan Alam, \\ Universitas Negeri Medan \\ ${ }^{2}$ Faculty of Physics \\ Universiti Sains Malaysia \\ E-mail: kdrmhmmd8@gmail.com
}

\begin{abstract}
Abtract
This study aimed to study the distribution of fluids, anomaly sightings and subsurface models from geothermal areas discussed in Penen village. Blue Biru District Deli Serdang Regency. The measurement of the geoelectric method is done by making the electrode path that injects current through the electrode. The potential difference that arises in the resistivity ABEM gauge can be measured by the apparent resistivity value obtained from the geoelectric device. Then the data is processed using Res2Div to get a 2D cross-section of the resistivity value of the rock layer. The analysis shows that the resistivity value (0.00-100) ohm-m and the throw layer model. Resistivity value (150-200) ohm-m model of the siltstone layer. The resistivity value (350-500) model of the sand layer ohm-m, and the resistivity value $>2250 \mathrm{ohm}-\mathrm{m}$ which identifies the limestone layer. From the results of this study, it can be concluded that Penen Village, Biru Biru Sub-District, Deli Serdang Regency supports having geothermal energy.
\end{abstract}

Keywords: Geoelectric, GPS, Susceptibility, Resistivity, Geothermal

\begin{abstract}
Abstrak
Tujuan dari penelitian ini adalah untuk mengetahui penyebaran fluida, penampang anomali dan model lapisan bawah permukaan dari daerah berpotensi geothermal tepatnya di desa Penen. Kecamatan Biru Biru Kabupaten Deli Serdang. Pengukuran metode geolistrik dilakukan dengan membuat lintasan elektroda yang menginjeksi arus melalui elektroda. Beda potensial yang muncul pada alat pengukur ABEM resistivity dapat terukur sehingga didapat harga resistivitas semu yang diperoleh dari alat geolistrik. Kemudian data diolah menggunakan Res2Div untuk mendapatkan penampang kontur 2D dari nilai resistivitas lapisan batuan. Hasil analisis menunjukkan bahwa nilai resistivitas $(0,00-100)$ ohm-m dan model lapisan batuan lempung. Nilai resistivitas (150 200) ohm-m model lapisan batuan lanau. Nilai restivitas (350 - 500) ohm-m model lapisan pasir, dan nilai restivitas $>2250 \mathrm{ohm}-m$ yang mengidentifikasikan lapisan batu gamping. Dari hasil penelitian ini dapat disimpulkan bahwa daerah Desa Penen Kecamatan Biru Biru Kabupaten Deli Serdang berpotensi memiliki energi panas bumi.
\end{abstract}

Kata kunci: Geolistrik, GPS, Suseptibilitas, Resistivity, Geothermal

\section{PENDAHULUAN}

Sekarang ini salah satu energi yang sangat diperlukan adalah energi listrik. Dengan semakin bertambahnya penduduk dan semakin tingginya kebutuhan dan alatalat elektronik yang membutuhkan energi listrik membuat kebutuhan energi listrik setiap tahun semakin meningkat, pada tahun 2014 saja di Indonesia kebutuhan energi listrik mencapai 31.550,95 MW, sedangkan kebutuhan energi listrik yang dibutuhkan di Indonesia pada tahun 2018 diperkirakan mencapai 64.000,00 MW.

Beberapa provinsi mengalami rasio elektrifikasi pasokan listrik diantaranya Papua Sumatera Utara (89,6\%), Kepulauan Riau (69,66\%), Gorontalo (67,81\%), Sulawesi Barat (67,6\%), Kalimantan Tengah $(66,21 \%)$, Nusa Tenggara Barat $(64,43 \%)$, Nusa Tenggara Timur (54,77\%), dan Papua 
$(36,41 \%)$. Sumatera utara merupakan provinsi dengan rasio paling tinggi. Sejak tahun 2005, krisis listrik di provinsi ini tidak terselesaikan. Kebutuhan listrik Sumut saat ini mencapai $1.700 \mathrm{MW}$, masih terdapat kekurangan pasokan mencapai $330 \mathrm{MW}$. Besaran kebutuhan ini, masih diluar daripada cadangan daya yang dibutuhkan. Maka salah satu cara untuk mengantisipasi jika terjadi gangguan pembangkit adalah dengan menggunakan energi alternatif (Budiyanti, 2014). Salah satu energi yang sangat berpotensi untuk dimanfaatkan adalah panas bumi (geothermal).

Geothermal dapat diartikan sebagai sumber daya panas alami, hasil interaksi antara panas yang dipancarkan batuan panas (magma) dan air tanah yang berada di sekitarnya, dimana cairan yang terpanasi akan terperangkap di dalam batuan yang terletak di dekat permukaan sehingga secara ekonomis dapat dimanfaatkan (Armstead, 1983). Karena terletak di daerah zona tumbukan antara lempeng eurasia dan lempeng indo-australia, maka potensi panas bumi di Indonesia menjadi sangat melimpah.

Hasil identifikasi Badan Geologi, ditemukan 265 lokasi yang memiliki potensi panas bumi. Sebanyak 138 lokasi (52,07\%) berada pada tahapan penyelidikan tingkat spekulatif dan 24 lokasi (9,05\%) berada pada tahapan penyelidikan tingkat spekulatif. Selain itu, terdapat pula 88 lokasi $(33,21 \%)$ yang telah ditetapkan memiliki cadangan panas bumi, dan terdapat 8 lokasi $(3,01 \%)$ yang telah siap untuk dikembangkan sebagai potensi panas bumi. Hingga saat ini, terdapat 7 lokasi $(2,64 \%)$ yang telah diberdayakan menjadi pembangkit listrik tenaga panas bumi (Badan Geologi, 2009).

Diperkirakan energi potensi panas bumi di Indonesia mencapai $27.500,00$ MW, yakni sumber potensi tersebut berada di Sumatera, Jawa, Nusa Tenggara, Maluku dan Papua. Sumatera Utara adalah salah satu provinsi yang paling banyak memiliki potensi energi panas bumi yaitu $1.857,00$ MW yang terdapat di enam kabupaten yakni, Karo, Simalungun, Tapanuli Utara, Tapanuli Selatan, Padang Lawas dan Mandailing Natal (Gunawan, 2013).

Menurut Nasution (2017), Sumatera Utara tidak akan kekurangan sumber energi listrik jika potensi panas bumi dimanfaatkan secara maksimal. Energi panas bumi yang telah dikembangkan di Sumatera Utara yaitu panas bumi Sarulla (330 MW) dan
Sibayak (120 MW), Dolok Marawan Kabupaten Simalungun dengan potensi cadangan terduga $38 \mathrm{MW}$ sedangkan masih ada beberapa daerah lain di Sumatera Utara yang memiliki potensi panas bumi dan belum dieksplorasi, diantaranya adalah daerah Penen Sibiru biru.

Untuk mengatasi krisis energi khususnya di Sumatera Utara adalah dengan memanfaatkan potensi panas bumi. Seharusnya pembangkit listrik tenaga panas bumi merupakan solusi alternatif untuk menyelesaikan masalah kekurangan energi. Kelebihan energi panas bumi yaitu ramah lingkungan dan termasuk energi yang tidak dapat diekspor sehingga pasokan energi listrik di negara Indonesia terus terjaga hingga ratusan tahun.

Eksplorasi panas bumi dapat diketahui dengan cara menentukan nilai resistivitas batuan dengan menggunakan beberapa metode yakni elektromagnetik, gravitasi, seismik, geomagnetik dan geolistrik. Dari beberapa metode dalam penentuan eksplorasi panas bumi banyak kelebihan jika menggunakan metode geolistrik. Metode geolistrik (resistivity) adalah metode eksplorasi geofisika yang digunakan untuk mengeksplorasi bahan tambang, dan juga untuk mengeksplorasi cadangan persediaan air dan eksplorasi panas bumi. Metode ini dirancang untuk memberikan informasi dari formasi batuan yang mempunyai anomali konduktivitas listrik.

Metode geolistrik dan magnetotelluric dapat digunakan untuk memetakan sedimen pada tahap awal eksplorasi minyak bumi (Broto, 2011). Dalam eksplorasi panas bumi, metode geolistrik digunakan untuk mengetahui potensi daerah panas bumi dengan mempelajari sifat aliran listrik pada batuan di bawah permukaan bumi.

Prinsip dasarnya yaitu menginjeksikan arus ke bawah permukaan melalui dua elektroda arus, dan mengukur besar tegangan di antara dua elektroda potensial (Arnata \& Musa, 2012). Dari penelitian sebelumnya metode yang efektif untuk mengetahui titik potensial panas bumi adalah dengan menggunakan metode geolistrik. Salah satu daerah yang sangat potensial memiliki energi panas bumi yaitu di desa Penen Kecamatan Biru Biru Kabupaten Deli Serdang.

Adanya titik potensial panas bumi daerah Penen dikarenakan berada pada posisi silang kawasan palung pasifik barat, sehingga terdapat sumber energi panas kawah putih dan kawah biru. Desa Penen 
merupakan salah satu daerah di sekitar panas bumi yang tidak mendapatkan pasokan energi listrik. Sehingga perlu dilakukan penelitian sebagai bahan pertimbangan pemerintah untuk membuat pembangkit listrik tenaga panas bumi supaya desa Penen tidak mengalami kekurangan energi dan dapat mengembangkan daerah di sekitar panas bumi yang berpengaruh pada kemajuan dibidang transportasi, komunikasi dan teknologi, dengan adanya pembangkit listrik di suatu daerah maka akan mempercepat kemajuan pembangunan. Jika potensi ini tidak dikembangkan maka pasokan listrik akan selalu mengalami kekurangan dan daerah sekitar menjadi tertinggal dalam hal teknologi dan komunikasi. Mengidentifikasi panas bumi di daerah Desa Penen diharapkan dapat menjadi solusi alternatif permasalahan energi. penelitian ini dilakukan sebagai bahan masukan dan menjadi solusi alternatif penyelesaian energi jika tidak dilakukan maka permasalahan energi akan selalu menjadi permasalahan.

Ruang lingkup dan batasan masalah yang dikaji dalam penelitian ini adalah metode yang digunakan adalah metode geolistrik, dengan batasan daerah kajian Desa Penen Kecamatan Biru Biru Kabupaten Deli Serdang, serta pengolahan data hasil penelitian menggunakan software Res2Dinv. Adapun rumusan masalah yang dalam penelitian ini adalah: (1) bagaimana struktur bawah permukaan serta kontur penyebaran fluida pada daerah panas bumi di desa Penen?; (2) bagaimana model struktur lapisan bawah permukaan daerah panas bumi di desa Penen?, dan (3) bagaimana pola penyebaran anomali geomagnet dan geolistrik berdasarkan sifat kemagnetan dan kelistrikan di desa Penen? Tujuan penelitian ini adalah untuk mengetahui struktur bawah permukaan serta kontur penyebaran fluida, model struktur lapisan bawah permukaan pada daerah panas bumi di Desa Penen, serta menganalisis penampang anomali bawah permukaan Desa Penen berdasarkan

\section{penampang anomali geolistrik.}

\section{METODOLOGI PENELITIAN}

Lokasi penelitian dilakukan di lahan geothermal Desa Penen, Kecamatan Biru Biru, Kabupaten Deli Serdang, Provinsi Sumatera Utara. Waktu penelitian dilaksanakan pada bulan April 2018. Alat yang digunakan adalam penelitian ini adalah: GPS (Global Position System), geolistrik Ares-D4.v47, aki/baterai, handy talky, compass, stopwatch, meteran, palu.

Teknik pengumpulan data dilakukan dengan pengukuran lapangan menggunakan Metode Geolistrik. Selain itu, beberapa data diperoleh dengan mengunduh dari Ares G-4 versi 4,7. Pengolahan dan analisis data dilakukan dengan menggunakan res2dinv.

\section{HASIL DAN PEMBAHASAN}

Secara interpretasi kuantitatif, daerah ini dapat digambarkan dengan melihat pendukung penelitian berupa peta geologinya. Berdasarkan Peta Geologi Lembar Medan, daerah Desa Penen didominasi oleh batu gamping, batu pasir, batu lempung dan batu lanau. Pada tampilan 2-D hasil dari pengolahan data menggunakan Software Res2Dinv dapat diamati bahwa lokasi penelitian terdiri dari tiga kontur resistivitas pada penampang kedalaman semu. Penampang pertama menunjukkan kontur pengukuran resistivitas semu (measured apparent resistivity), yaitu data resistivitas semu yang diperoleh dari pengukuran lapangan. Sedangkan penampang kedua menunjukkan kontur resistivitas dari hasil perhitungan (calculate apparent resistivity).

\section{Lintasan I}

Data yang diperoleh dengan menggunakan alat geolistrik (Restivity Meter), adalah nilai resistivitas semu bervariasi dikarenakan struktur bawah permukaan sangat bervariasi, nilai resistivity 0,00 $\Omega m$ sampai $15000 \Omega m$ panjang lintasan 155 meter dengan 32 elektroda dan jarak antara elektroda 5 meter dengan kedalaman maksimal 28,7 m. Diinversikan dengan software Res2Dinv diperoleh gambar penampang 1 berikut: 


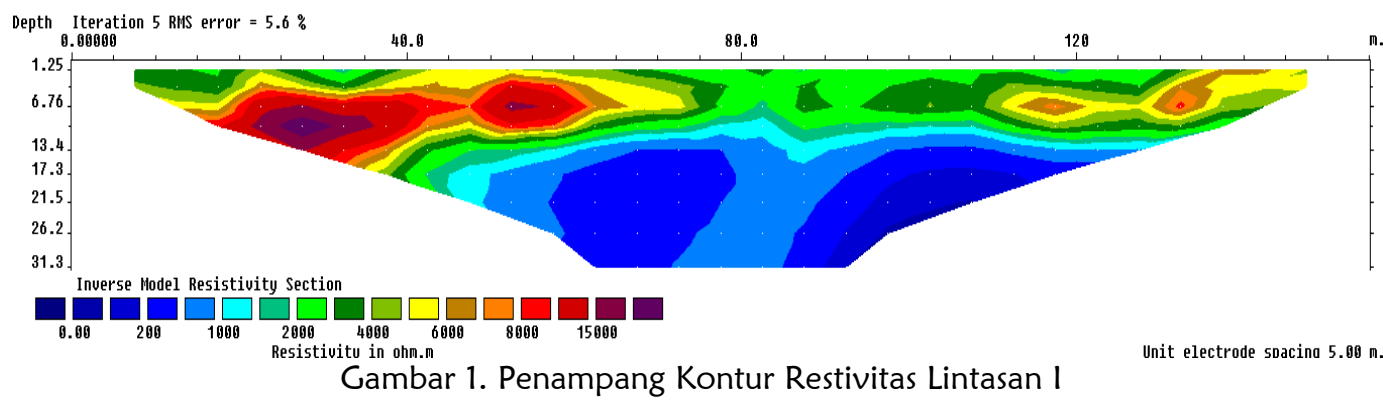

Berdasarkan gambar 1. untuk nilai resistivitas 0,00-100 $\Omega m$ terletak pada kedalaman 13-31,3 m dengan jarak 50-130 $m$ ditafsirkan sebagai lempung. Nilai resistivitas 150-200 $\Omega m$ terletak pada kedalaman 50-130 m dengan jarak 150$2000 \mathrm{~m}$ ditafsirkan sebagai lanau. Nilai restivitas 500-1000 $\Omega m$ terletak pada kedalaman 17,3-20 m dengan jarak 40-130 $\mathrm{m}$ ditafsirkan sebagai batu pasir, dan untuk nilai restivitas $>5000 \Omega m$ ditafsirkan sebagai batu gamping yang terletak pada kedalaman 6,76- 17,3 m dengan jarak antara $10-61 \mathrm{~m}$.

Hasil penampang resistivitas menunjukkan bahwa adanya perbedaan nilai restivitas pada tiap lapisan. Untuk lintasan 1 umumnya didominasi oleh lapisan yang memiliki nilai resistivitas $0-200 \Omega m$ yang ditafsirkan sebagai lempung. Anomali rendah terdapat pada kedalaman 6,76-17,3 $\mathrm{m}$ dengan jarak 10- $61 \mathrm{~m}$ memiliki nilai resistivitas $>5000 \Omega m$ dengan merah muda sampai merah tua Anomali tinggi ini ditafsirkan sebagai gamping.

Menurut (Lénat, Fitterman, Jackson, \& Labazuy, 2000), nilai resistivitas berbanding terbalik dengan nilai konduktivitas batuan, dimana semakin konduktif suatu batuan maka nilai resistivitasnya akan semakin kecil. Hal ini disebabkan adanya porositas yang besar yang terisi oleh fluida panas bumi terutama air dalam kondisi panas tinggi.

\section{Lintasan II}

Data yang diperoleh dengan menggunakan alat geolistrik (Restivity Meter), adalah nilai resistivitas semu bervariasi dikarenakan struktur bawah permukaan sangat bervariasi, nilai resistivity $0,00 \Omega m$ sampai $18000 \Omega m$. panjang lintasan 155 meter dengan 32 elektroda dan jarak antara elektroda 5 meter dengan kedalaman maksimal 21,7 m. Diinversikan dengan software Res2Dinv diperoleh gambar penampang 2 . berikut:

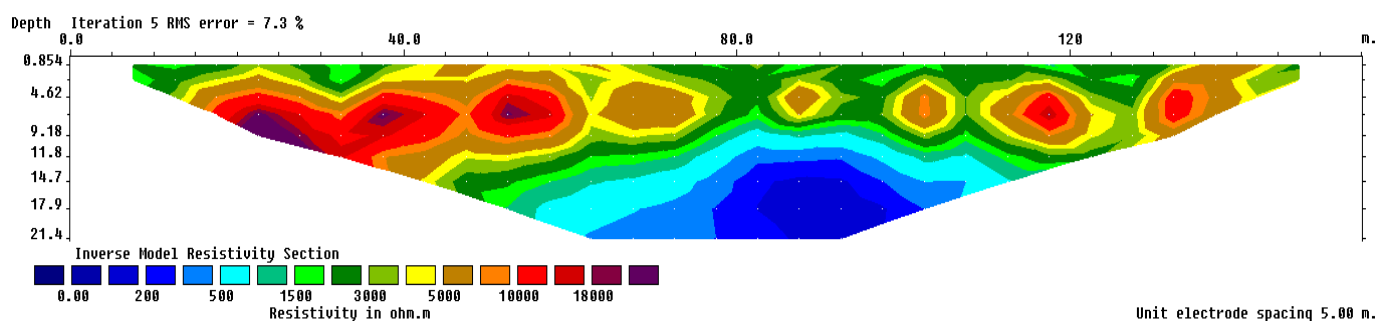

Gambar 2. Penampang Kontur Restivitas Lintasan II

Berdasarkan gambar 2 untuk nilai resistivitas 0-100 $\Omega m$ terletak pada kedalaman 10-21,7 m dengan jarak 50- 110 $m$ ditafsirkan sebagai lempung. Nilai resistivitas 150-200 $\Omega m$ terletak pada kedalaman 9,39- 28,7 m dengan jarak 68$97,5 \mathrm{~m}$ ditafsirkan sebagai lanau. Nilai restivitas 500-1500

$\Omega m$ terletak pada kedalaman 10-21,4 m dengan jarak 50-110,5 m ditafsirkan sebagai batu pasir, dan untuk nilai restivitas $>5000$ $\Omega m$ ditafsirkan sebagai batu gamping yang terletak pada kedalaman 5- $130 \mathrm{~m}$ dengan jarak antara 4-14,5 m.

Hasil penampang resistivitas menunjukkan bahwa adanya perbedaan nilai restivitas pada tiap lapisan. Untuk lintasan II umumnya didominasi oleh lapisan yang memiliki nilai resistivitas $>5000 \Omega m$ yang ditafsirkan sebagai batu gamping. Anomali 
rendah terdapat pada kedalaman 10-21,7 m dengan jarak 68-97,5 m memiliki nilai resistivitas 50-100 $\Omega m$ dengan warna biru tua sampai biru muda Anomali rendah ini ditafsirkan sebagai lempung.

Dapat ditafsirkan lapisan yang berpotensi sebagai geothermal adalah lapisan yang berada pada kedalaman 10-21,7 dengan jarak 68-97,5 m dengan nilai resistivitas 50$100 \Omega m$ yakni lapisan lempung. Berdasarkan hasil analisa terlihat bahwa pada daerah penelitian terdapat tiga lapisan tanah yang tersusun atas lempung, pasir dan gamping. Hasil inverse dari kedua lintasan didominasi oleh batuan gamping.

\section{KESIMPULAN}

Dari hasil penelitian yang dilakukan maka dapat diambil kesimpulan antara lain:

1. Nilai resistivitas pada lintasan I antara 0,00- $100 \Omega m$ dan lintasan II antara 50$100 \Omega m$ yakni lapisan lempung sebagai zona konduktif manifestasi panas bumi. Untuk lapisan penudung berupa batu gamping.

2. Berdasarkan nilai resistivitas yang diperoleh nilai resistivitas $(0,00-100)$ $\Omega m$ dan model lapisan batuan lempung. Nilai resistivitas (150-200) $\Omega m$ model lapisan batuan lanau. Nilai restivitas (350 - 500) $\Omega m$ model lapisan pasir, dan nilai restivitas $>5000 \Omega m$ model lapisan batu gamping.

3. Hasil dari nilai suseptibilitas dan nilai resistivitas pada daerah Desa Penen memiliki lapisan yang sesuai.

\section{DAFTAR PUSTAKA}

Armstead, H. C. H. (1983). Geothermal Energy: Its Past, Present and Future Contribution to the Energy Needs of Man. E. \& FN Spon: New York.

Arnata, D. P. B., \& Musa, M. D. (2012). Identifikasi Sistem Panas Bumi Di Desa Masaingi Dengan Menggunakan Metode Geolistrik. Jurnal Natural Science, 1(1), 1-6.

Badan Geologi. (2009). Panas Bumi Di Indonesia. Retrieved September 6, 2015, from http://psdg.bgl.esdm.go.id

Broto, S. (2011). Aplikasi metode geomagnet dalam eksplorasi panasbumi. Teknik, 32(1), 79-87.

Budiyanti, E. (2014). Mengatasi Krisis Listrik di Jawa dan Sumatra. Pusat Pengkajian, Pengolahan Data Dan Informasi (P3DI) Sekretariat Jenderal DPR RI.
Gunawan, H. (2013). Potensi Panas Bumi di Samosir Siap Dilelang Tribunnews.com. Retrieved October 2, 2015, from https://www.tribunnews.com/bisnis/ 2013/05/01/potensi-panas-bumi-disamosir-siap-dilelang

Lénat, J.-F., Fitterman, D., Jackson, D. B., \& Labazuy, P. (2000). Geoelectrical structure of the central zone of Piton de la Fournaise volcano (Réunion). Bulletin of Volcanology, 62(2), 7589.

Nasution, Z. (2017). Pembangkit Listrik Tenaga Panas Bumi di Sumatera Utara | DR. Arif Zulkifli Nasution. Retrieved November 7, 2017, from https://bangazul.com/pembangkitlistrik-tenaga-panas-bumi-di-sumaterautara/ 
available at http://jurnal.unimed.ac.id/2012/index.php/tgeo e-ISSN: 2622-9528 p-ISSN: 2301-606X
Jurnal Tunas Geografi Vol. 08 No. $01-2019$ 